\title{
MENINGKATKAN HASIL BELAJAR SISWA DENGAN \\ METODE COOPERATIVE LEARNING \\ PADA MATA PELAJARAN IPS DI SDN NO.3 TEROS
}

\author{
Nasri \\ STIT Palapa Nusantara \\ Email: nasriazkia190@gmail.com
}

\begin{abstract}
Abstrak: Penelitian tindakan kelas ini bertujuan meningkatkan prestasi hasil belajar siswa dengan penerapan metode cooperatif learning. Penelitian tindakan kelas ini dilakukan karena dalam proses pembelajaran masih ditemukan masalah atau hambatan terhadap guru maupun siswa yang melaksanakan kegiatan pembelajaran. Penelitian tindakan kelas ini terdiri dari dua siklus yaitu siklus pertama dan siklus ke dua, dimana dalam setiap siklus terdiri atas perencanaan tindakan, pelaksanaan tindakan, obsevasi dan refleksi. Penelitian ini dilaksaanakan pada siswa kelas V SD Negeri No.3 Teros pada semester ke dua tahun pelajaran 2016/2017. Pengumpulan data pada siklus satu dan siklus dua menggunakan tes subyektif atau pilihan ganda yang dibuktikan dengan analisis serta hasil dari observasi yang membantu peneliti dalam proses belajar mengajar. Penelitian ini bertujuan untuk meningkatkan prestasi hasil belajar siswa, hasil penelitian menunjukkan mengalami peningkatan sebesar 37\%. Hasil belajar siswa rata-rata mencapai 62 menjadi 89 hasil ini mengalami peningkatan sebesar $27 \%$.
\end{abstract}

Kata Kunci: Hasil Belajar, Metode Kooperatif Learning

\section{Pendahuluan}

Pendidikan adalah sesuatu yang esensial atau penting dalam kehidupan. Baik kehidupan berbangsa dan bernegara, bermasyarakat maupun dalam kehidupan berkeluarga. Banyak faktor yang mempengaruhi keberhasilan dalam dunia pendidikan. Faktor tersebut antara lain adalah kurikulum, sarana prasarana, dan terutama faktor tertentu dari keberhasilan tersebut adalah guru sebagai tenaga pendidik.

Berdasarkan temuan penulis, sebagian besar siswa kurang aktif dan tidak mampu berfikir kritis dalam materi berorganisasi, anak belum mampu berpikir kritis dan menemukan solusi dengan benar sehingga banyak anak yang menjawab salah dengan alasan soalnya sulit. Karena itu wajar setiap kali diadakan tes, nilai pelajaran IPS selalu rendah dengan rata-rata kurang dari KKM. Seperti yang dialami penulis 
sendiri, setiap ulangan IPS nilai rata-rata anak di bawah 70. Termasuk pada materi Berorganisasi.

Menghadapi kenyataan tersebut di atas, penulis tertarik untuk mendalami metode dan pendekatan yang dapat memberikan jawaban atas persoalan-persoalan yang dihadapi, dan melakukan beberapa tindakan-tindakan evaluasi pada proses pembelajaran IPS, khususnya pada materi berorganisasi. Perbaikan yang akan penulis lakukan terutama dalam menerapkan metode Cooprative Learning dalam materi berorganisasi. Harapan penulis adalah terjadinya proses pembelajaran yang aktif, kreatif, dan menyenangkan, sehingga terlihat lebih bermakna dan peserta didik juga mampu memahami secara keseluruhan materi yang disampaikan oleh guru.

Berdasrkan latar belakang di atas, terdapat beberapa masalah dalam proses pembelajaran sebagai berikut.

a. Siswa kurang memahami tentang organisasi

b. Siswa kurang aktif dalam diskusi kelompok

d. Siswa tidak berani mengeluarkan pendapat

e. beberapa orang siswa selalu mengantuk

f. Siswa tidak berani bertanya

g. Hasil belajar siswa rendah

\section{Tujuan Penelitian}

Penelitian ini bertujuan untuk mengetahui apakah dengan menggunakan metode kooperatif learning dapat meningkatkan hasil belajar siswa kelas V pada mata pelajaran IPS dengan materi berorganisasi?.

\section{Kajian Pustaka}

\section{Pengertian Prestasi Hasil Belajar.}

Menurut Andayani hasil belajar merupakan perubahan prilaku yang diperoleh melalui proses pembelajaran. ${ }^{1}$ Begitu juga hasil belajar adalah perubahan prilaku yang relatif menetap dalam diri seseorang sebagai akibat dari interaksi seseorang dengan lingkungan ${ }^{2}$.

Berdasarkan pengertian hasil belajar di atas perubahan prilaku tersebut tergantung pada apa yang dipelajari, maka perubahan prilaku yang diperoleh berupa

1 Andayani, dkk., Pemantapan kemampuan profesioanl, (Jakarta: Universitas Terbuka, 2010), 23.

2 Ibid, 43. 
penguasaan konsep. Dalam pembelajara IPS pada materi Organisasi, melalui aktivitas tersebut akan lebih bermakna bagi siswa, oleh karena itu siswa juga perlu berintraksi dengan siswa yang lain untuk membuat simpulan yang benar.

Dalam penelitian ini hasil belajar pada pelajaran IPS dengan materi Organisasi pada siswa kelas No.3 Teros yang diukur melalui tes formatif dengan KKM 70. Maka siswa yang berjumlah 27 orang siswa sebagaian besar mendapat nilai dibawah KKM. Bagi siswa yang nilainya kurang dari target diberikan soal perbaikan/remidial, kemudian bagi siswa yang memenuhi standar ke atas diberika soal pengayaan dalam bentuk menjawab essay.

Secara khusus Aswani telah mengklasifikasikan dalam empat kelompok seperti berikut ${ }^{3}$ :

1. Kelompok Pengolahan Informasi, terdiridari :

- Model pencapaian konsep

- Model berpikir Induktif (Induktiv Thinking)

- Pemandu Awal (Advance Organizez)

- Latihan Penelitian (Inquiri Training)

- Pengorganisasian

2. Kelompok Interaksi Sosial atau "Social models ", terdiri dari :

- Bermain Peran (Rule Playing)

- Investigasi kelompok dan

- Model Inquiri Studi Social

3. Kelompok Personal atau "Personal models ", Terdiri dari :

- Pembelajaran tanpa arah

- Model Sentitik

- Model Pertemuan Kelas (Classroom meetting)

4. Kelompok Prilaku atau "Behavioral system ",terdiri dari :

- Kontrol diri melalui methode operan

- Latihan pengungkapan perasaan secara jujur dan langsung

3ZZainul Aswani, 2005, Komputer dan media Pembelajaran, (Jakarta: Universitas Terbuka), 65. 
- Belajar tuntas (masterylearning) ${ }^{4}$

\section{Peran beroganisasi dalam pembelajaran IPS di SD}

Organisasi adalah merupakan Suatu sistim aktivitas

kerja sama yang dilakukan oleh dua orang atau lebih. Faktor penyebab keberhasilan siswa tergantung dari kelompok kerja atau belajar, maka dalam kelompok kerja itu bisa juga disebut sebagai organisasi. Jadi tujuan yang dimaksudkan adalah:

a. Untuk memotivasi siswa.

b. Untuk menarik minat dan perhatian siswa

c. Memberikan kesempatan kepada siswa untuk mengeksplorasisituasi dimana mengalami emosi,perbedaan pendapat,dan permasalahan dalam lingkungan kehidupan sosial anak

d. Menarik siswa untuk bertanya

e. Mengembangkan kemampuan komonikasi siswa.

f. Melatih siswa untuk berperanaktif dalam kehidupan. ${ }^{5}$

Diperjelas pula dengan pendapat dari Stephen P.Robbins, Menyatakan bahwa Organisasi adalah kesatuan (Entity) sosial yang dikordinasikan sacara sadar dengan "sebuah batasan yang relatif dapat diidentifikasi yang bekerja sama atas dasar yang relatif terus menerus untuk mencapai tujuan bersama atau sekelompok tujuan".

Dalam mata pelajaran IPS kelas $\mathrm{V}$ pada semester 2 ada materi tentang kebebasan berorganisasi,dalam materi ini organisasi merupakan suatu perkumpulan yang anggotanya terdiri atas beberapa orang yang bekerja sama dengan upaya mencapai tujuan bersama,jadi tujuan dibentuknya organisai agar suatu kegiatan bejalan lancar dan dapat mencapai tujuan.

Ada beberapa macam organisasi yang ada disekolah dan di masyarakat sebagai contoh antara lain:

1. Macam-macam Organisasi Sekolah yaitu, OSIS, Komite Sekolah, Pramuka, PMR, UKS dan Koperasi Sekolah.

\footnotetext{
${ }^{4}$ A. Malik Fadjar, Reorientasi Pendidikan Islam, (Jakarta : Fajar Dunia, 1999), 43.

${ }_{5}^{5}$ BNSP, Standar Isi Kompetensi Dasar Mata Pelajaran Pendidikan Kewarganegaraan SD kelas V, (Jakarta: Erlangga, 2006), 76.
} 
2. Macam-macam Organisasi Masyarakat yaitu, RT, Karang Taruna, PKK, Posyandu dan lain sebagainya. ${ }^{6}$

\section{Kerangka Berpikir}

Di dalam proses belajar mengajar, guru harus memiliki strategi agar siswa dapat belajar secara efektif dan efisiensi sesuai pada tujuan yang diharapkan. Salah satu strategi yang harus dimiliki oleh guru adalah harus menguasai teknik-tehnik penyajian atau bisa disebut methode mengajar.

Dengan model pembelajaran cooperative learning, diharapkan siswa dapat lebih aktif dan prestasi hasil belajar lebih meningkat pada mata pelajaran IPS dan dapat memberikan solusi dalam memahami materi, serta memberikan keaktifan, perhatian, belajar memecahkan masalah yang dapat berpengaruh positif terhadap hasil belajar siswa dalam rangka perbaikan proses belajar mengajar.

\section{Metode Penelitian}

\section{Setting Penelitian}

\section{Subyek penelitian}

Subyek penelitian ini dilaksanakan pada kelas V No.3 Teros, kecamatan Labuhan Haji Kabupaten Lombok Timur,semester II tahun pelajaran 2016/2017 yang berjumlah 27 orang siswa yang terdiri dari laki-laki 12 orang dan perempuan 15 orang siswa dengan usia rata - rata 11 tahun .Pada saat peneliti melaksanakan penelitian tindakan kelas jumlah siswa secara keseluruhan berjumlah 158 orang siswa dari kelas 1 sampai dengan kelas 6 .

\section{Obyek Penelitian}

Obyek penelitian ini adalah methode pembelajaran cooperatif learning. Methode ooperatif learning ini memang setelah di laksanakan oleh peneliti di lain waktu dan dilai kelas peneliti menemukan suatu keberhasilan, sehingga peneliti mengambil menetapkan untuk digunaka pada pelajaran PKn dengan materi berorganisasi ,karena proses pembelajarannya menggunakan kelompok atau bermain peran.

\footnotetext{
${ }^{6}$ Rahayu Setiati dan Fajar Ningsih, PKn SD/MI kelas V, Pusat Perbukuan: Jakarta: Pusat
} Perbukuan, 2008), 24. 


\section{a. Tempat Penelitian}

Penelitian ini dilaksanakan di kelas V SDN No.3 Teros,Unit Pendidikan dan Kebudayaan kecamatan Labuhan Haji Kabupaten Lombok Timur tahun pelajaran 2016 / 2017.

Sekolah Dasar Negeri No.3 Teros terletak di Desa Teros Kecamatan Labuhan Haji Kabupaten Lombok Timur, Sekolah tersebut berada di pinggir jalan yang sudah di aspal jurusan Tanjung dan dekat dengan pemukiman warga setempat yang masih agak Padat penduduknya. SDN No.3 Teros didirikan pada tahun 1983, jarak SDN No.3 Teros dengan kota kecamatan sekitar $3,5 \mathrm{~km}$ juga jalannya ber spal dan jarak SDN No.3 Teros ke kota Kabupaten sekitar kurang lebih 8 km.

\section{Waktu Penelitian}

Penelitian ini dilakukan dengan dua siklus yaitu siklus I tiga kali pertemuan yang diawali dengan pra siklus dan dilanjutkan dengan pertemuan pertama ke II dan ke III, siklus II dilaksanakan 2 kali pertemuan yang diawali dengan pertemuan pertama proses belajar mengajar dan pertemuan ke dua pelaksanaan evaluasi .Penelitian ini dilaksanakan selama kurun waktu empat bulan, yaitu mulai dari tanggal , 11 Januari sampai dengan 26 april 2017.

\section{Prosudur Penelitian}

Prosidur penelitian ini ditetapkan dalam dua siklus yang dilakukan dari prasiklus mulai dari perencanaan, pelaksanaan, observasi,analisis/refleksi hingga sampai pada siklus ke dua.

\section{Pelaksanaan Siklus I}

Siklus ini dilaksanakan selama dua kali pertemuan, dimana setiap pertemuan beralokasi 2 jam pelajaran atau 2 x 35 menit. Penelitian ini digunakan untuk meningkatkan hasil belajar IPS dalam materi berorganisasi dengan menerapkan methode Cooperatif Learning, sehingga peneliti merencanakan :
a) Membuat Sknario Pembelajaran
b) Membuat format Pembelajaran
c) Menyiapkan bahan dan alat yang digunakan dalam proses pembelajaran
d) Membuat alat / instrumen penilaian
e) Merancang tehnik Penilaian
f) Menyiapkan lember pengamatan guru. 


\section{Pelaksanaan Tindakan}

Pelaksanaan pembelajaran siklus I dimulai dari prasiklus, yang dilaksanakan masing-masing kelas selama kurun waktu 2 jam, dan dilaksanakan pada bulan maret. Tahap I dilaksanakan pada setiap hari rabu minggu ke 2, ke 3, dan ke 4 tanggal 08 Maret 2017, tanggal 15 maret 2017 dan tanggal 22 maret 2017. Adapun pelaksanaan pembelajaran dijelaskan seperti langkah-langkah berikut ini:

1. Guru penjelaskan sederhana tentang Organisasi

2. Guru mengajak siswa menyebutkan berbagai organisasi

3. Guru memberikan penjelasan sederhana tentang manfaaf berorganisasi

4. Guru membagi siswa menjadi kelompok-kelomp[ok

5. Guru menjelaskan cara untuk mengisi lembar kerja siswa

6. Guru membagi lembar kerja siswa

7. Setiap kelompok menunjuk salah satu anggota untuk mempersentasikan dimuka kelas

8. Siswa dari kelompok lain memberikan tanggapan dan menghargai pendapat teman

9. Guru membimbing siswa mempersentasikan dari hasil tanggapan masingmasing kelompok

10. Guru membrikan tanggapan dan penguatan terhadap semua kelompok.

\section{Obsevasi}

Pengamatan yang dilakukan oleh observer terhadap pelaksanaan PTK ini maka peneliti menitik beratkan pada penggunaan metode cooperatip learniing, dan hasil yang diperoleh dengan menggunakan tes subyektif pada akhir siklus. Data yang diperoleh berupa angka mengenai nilai yang diperoleh masing-masing siswa terhadap soal yang diterapkan setelah diterapkan methode Cooperatif learning dalam peroses pembelajaran IPS ,jumlah Soal yang diberikan dalam tes ini adalah 10 soal tipe pilihan ganda. Pengelompokan nilai siswa pada siklus I lebih jelasnya dapat dilihat pada tabel berikut ini

Tabel Pengelompokan nilai siklus I,

\begin{tabular}{|l|l|c|l|}
\hline No & Kriteria & Rentang Nilai & Frekwansi \\
\hline 1 & Kurang Sekali & $<59$ & 8 \\
\hline 2 & Kurang & $60-69$ & 10 \\
\hline
\end{tabular}




\begin{tabular}{|l|l|l|l|}
\hline 3 & Cukup & $70-79$ & 3 \\
\hline 4 & Baik & $80-89$ & 6 \\
\hline 5 & Baik Sekali & $90>$ & - \\
\hline
\end{tabular}

\section{Analisis dan Refleksi}

Refleksi dilakukan berdasarkan hasil belajar Pkn materi berorganisasi dengan menggunakan metode cooperatif learning pada siswa kelas V SDN No.3 Teros. Hal ini dilakukan untuk mengetahui hasil belajar yang diperoleh siswa dengan menggunakan methode cooperatif learnung. Pada tahap ini peneliti mengadakan kegiatan sebagai berikut :

1. Mengamati tehnik model pembelajaran yang di lakukan .

2. Mengidentifikasi masalah yang timbul.

3. Merumuskan alternative tindakan yang akan dilakukan selanjutnya.

4. Menyusun rencana untuk pertemuan minggu berikutnya.

\section{Siklus II}

Pelaksanaan perbaikan pembelajaran yang dilaksanakan pada siklus II, meliputi ;Perencanaan ,pelaksanaan,obsevasi dan analisis refleksi. Secara lebih rinci diuraikan sebagai berikut.

\section{Perencanaan Siklus II}

1.Merancang tehnik yang akan dilakukan dalam pembelajaran

2.Membuat format pembelajatran

3.Menyiapkan alat dan sumber bahan yang akan digunakan dalam proses pembelajaran

4.Menyiapkan alat penilaian / instrumen penilaian

5.Menyiapkan Format penilaian

\section{Pelaksanaan Siklus II}

Pelaksanaan tindakan pada siklus II pertemuan I dilaksanakan pada hari rabu tanggal 29 Maret 2017 pembelajaran awal dilaksanakan selama 2 jam pelajaran dalam proses, dan pertemuan II dilaksanaan hari rabu tanggal 5 april 2017 dalam bentuk evaluasi /ulangan. Langkah - langkah yang dilakukan pada pertemuan II siklus II sebagai berikut :

1. Guru memberikan penjelasan sederhana tentang organisasi 
2. Mengajak siswa menyebutkan berbagai organisasi

3. Guru memberika penjalasan sederhana tentang mamfaat berorganisasi

4. Guru membagi siswa menjadi kelompok-kelompok

5. Guru menjelaskan cara untuk mengisi lembar kerja siswa

6. Guru membagikan lembar kerja siswa

7. Setiap kelompok menunjuk salah satu anggota untuk mempersentasikan dimuka kelas

8. Siswa dari kelompok lain memberikan tanggapan dan menghargai hasil pekerjaan teman

9. Guru membimbing siswa mempersentasikan dan hasil tanggapan masingmasing kelompok

10. Guru memberikan tanggapan dan penguatan terhadap semua kelompok

\section{Observasi}

Pengamatan yang dilakukan peneliti menitik beratkan pada penggunaan methode cooperatip learning, dan hasil yang diperoleh dengan menggunakan bentuk tes subyektif pada akhir siklus. Data yang diperoleh berupa angaka mengenai nilai yang diperoleh masing-masing siswa terhadap soal yang dikerjakan setelah diterapkan methode cooperatif learning dalam proses pembelajaran IPS dengan materi contoh berorganisasi disekolah dan masyarakar beserta fungsinya .

Hasil belajar siswa pada siklus II ini dapat dikelompokkan berdasarkan rentang nilainya. Pengelompokan nilai siswa pada siklus II untuk lebih jelasnya dapat dilihat pada tabel berikut ini,

\begin{tabular}{|l|l|l|l|}
\hline No & Kriteria & Rentang Nilai & Frekwansi \\
\hline 1 & Kurang Sekali & $<59$ & - \\
\hline 2 & Kurang & $60-69$ & 3 \\
\hline 3 & Cukup & $70-79$ & 13 \\
\hline 4 & Baik & $80-89$ & 7 \\
\hline 5 & Baik Sekali & $90>$ & 4 \\
\hline
\end{tabular}

\section{Refleksi}


Refleksi dilakukan terhadap hasil observasi dan evaluasi kegiatan pembelajaran. Refleksi dilakukan dengan tujuan untuk mengkaji apakah pembelajaran PKn materi berorganisasi menggunakan methode cooperatiflearning cocok atau tidak dalam pembelajaran IPS kelas 5 , atau mungkin melihat kendala -kendala yang terjadi selama proses pembelajaran berlangsung berkaitan dengan hasil belajar yang dicapai siswa.Dalam hal ini kalau kita melihat dari hasil pada siklus I dengan siklus II memuaskan ,meskipun demikian perlu untuk meneliti dan memprdalam pada penelitian selanjutnya dengan menggunakan cara lain pula.

\section{Pembahasan}

Dengan menggunakan pendekatan model cooperatif learning di kelas $V$ SDN No.3 Teros terjadi peningkatan prestasi hasil belajar dengan menggunakan model pembelajaran ini memang dibutuhkan untuk membantu siswa dalam pelajaran Pendidikan kewarganegaraan yang diukur dari scor rata-rata aktivitasbelajar dan aktivitas kerja sama menunjukkan bahwa ada peningkatan dari siklus I ke siklus II .

Rata-rata aktivitas siswa pada siklus I adalah 62 dengan klasikal cukup aktif,dan pada siklus II adalah 78 dengan klasikal aktif,berarti ada peningkatan aktivitas siswa dalam pembelajaran pada siklus II ,karena siswa diberikan keleluasan dalam berpartisipasi aktif saat melakukan aktivitas pembelajaran

Hasil evaluasi belajar sudah baik walaupun masih ada siswa yang nilainya dibawah kriteria ketuntasan, namun nilai siswa rata-rata kriteria bahkan melebihi dari tingkat ketuntasan .Berdasarkan hasil belajar siswa yang berkaitan dengan upaya meningkatan hasil belajar materi berorganisasi mata pelajaran IPS menggunakan methode cooperatif learning ditunjukkan dengan nilai rata-rata diatas ketuntasan, yang dilaksanakan pada siklus II adalah 78 termasuk kata gori baik dan ketuntasan belajarnya adalah 94,80, \%.

Untuk melihat suatu perbandingan dari masing-masing siklus yang peneliti gambarkan sesuai dengan hasil yang di capai baik siklus I maupun siklus II merupakan hasil antar siklus digambarkan dalam tabel berikut ini; 
Tabel Hasil siklus I

\begin{tabular}{|c|c|c|c|c|}
\hline \multirow[b]{2}{*}{ No } & \multirow[b]{2}{*}{ Nama Siswa } & \multirow[b]{2}{*}{ Nilai } & \multicolumn{2}{|c|}{ Ketuntasan } \\
\hline & & & $\mathrm{Ya}$ & tidak \\
\hline 1 & Ahmad Yusuf & 50 & & $\mathrm{~V}$ \\
\hline 2 & Arman Dwi Ilham & 60 & & $\mathrm{~V}$ \\
\hline 3 & Dana Maulana & 60 & & $\mathrm{~V}$ \\
\hline 4 & Ezi Putrawan & 80 & $\mathrm{~V}$ & \\
\hline 5 & Halimah & 60 & & $\mathrm{~V}$ \\
\hline 6 & Huswatun Hasanah & 60 & & $\mathrm{~V}$ \\
\hline 7 & Hasniati & 80 & $\mathrm{~V}$ & \\
\hline 8 & Hirfandi & 70 & $\mathrm{~V}$ & \\
\hline 9 & Ida Handayani & 60 & & $\mathrm{~V}$ \\
\hline 10 & Jefrian Abdullah & 60 & & $\mathrm{~V}$ \\
\hline 11 & Lilis Cahyani & 60 & & $\mathrm{~V}$ \\
\hline 12 & Muh,Irwan Hadi & 50 & & $\mathrm{~V}$ \\
\hline 13 & Muh Riski Maulidi & 80 & $\mathrm{~V}$ & \\
\hline 14 & Nurul Suhada & 40 & & $\mathrm{~V}$ \\
\hline 15 & Nurhidayah & 80 & $\mathrm{~V}$ & \\
\hline 16 & Rani Rahmawati & 40 & & $\mathrm{~V}$ \\
\hline 17 & Rozali & 90 & $\mathrm{~V}$ & \\
\hline 18 & Riyan Sahasbi & 90 & $\mathrm{~V}$ & \\
\hline 19 & Suriani & 50 & & $\mathrm{~V}$ \\
\hline 20 & Wahyu Ade Sastrawan & 60 & & $\mathrm{~V}$ \\
\hline 21 & Yeni Regina & 70 & $\mathrm{~V}$ & \\
\hline 22 & Wendi Aulia Febrian & 40 & & $\mathrm{~V}$ \\
\hline 23 & Legina Fatmawati & 50 & & $\mathrm{~V}$ \\
\hline 24 & Nur azizah & 70 & $\mathrm{~V}$ & \\
\hline
\end{tabular}




\begin{tabular}{|l|l|l|l|l|}
\hline 25 & Evi Susanti & 70 & V & \\
\hline 26 & Nurul Aini & 40 & & V \\
\hline 27 & Sandi Hariawan & 60 & & V \\
\hline Jumlah & 1680 & 10 & 17 \\
\hline \multicolumn{2}{|l|}{ Rata-rata } & $\mathbf{6 2}$ & $\mathbf{3 7}$ & $\mathbf{6 3}$ \\
\hline
\end{tabular}

Keterangan :

- Tuntas : $\underline{10 \times 100}=37$

27

- Belum Tuntas : $\underline{17 \times 100}=63$

Tabel Hasil Siklus II

\begin{tabular}{|l|l|l|l|l|}
\hline \multirow{2}{*}{ No } & & \multicolumn{3}{|l|}{ Ketuntasan } \\
\cline { 4 - 5 } & Nama Siswa & Nilai & Ya & tidak \\
\hline 1 & Ahmad Yusuf & 80 & V & \\
\hline 2 & Arman Dwi Ilham & 70 & V & \\
\hline 3 & Dana Maulana & 90 & V & \\
\hline 4 & Ezi Putrawan & 90 & V & \\
\hline 5 & Halimah & 80 & V & \\
\hline 6 & Huswatun Hasanah & 80 & V & \\
\hline 7 & Hasniati & 80 & V & \\
\hline 8 & Hirfandi & 70 & V & \\
\hline 9 & Ida Handayani & 70 & V & \\
\hline 10 & Jefrian Abdullah & 70 & V & \\
\hline 11 & Lilis Cahyani & 70 & V & \\
\hline 12 & Muh,Irwan Hadi & 60 & & V \\
\hline 13 & Muh Riski Maulidi & 80 & V & \\
\hline & & & & \\
\hline
\end{tabular}




\begin{tabular}{|l|l|l|l|l|}
\hline 14 & Nurul Suhada & 60 & & V \\
\hline 15 & Nurhidayah & 80 & V & \\
\hline 16 & Rani Rahmawati & 70 & V & \\
\hline 17 & Rozali & 90 & V & \\
\hline 18 & Riyan Sahasbi & 90 & V & \\
\hline 19 & Suriani & 70 & V & \\
\hline 20 & Wahyu Ade Sastrawan & 70 & V & \\
\hline 21 & Yeni Regina & 70 & V & \\
\hline 22 & Wendi Aulia Febrian & 60 & & V \\
\hline 23 & Legina Fatmawati & 70 & V & \\
\hline 24 & Nur azizah & 70 & V & \\
\hline 25 & Evi Susanti & 70 & V & \\
\hline 26 & Nurul Aini & 80 & V & \\
\hline 27 & Sandi Hariawan & 70 & V & \\
\hline Jumlah & $\mathbf{9 4 , 8 0}$ & $\mathbf{8 9}$ & $\mathbf{1 1}$ \\
\hline Rata-rata & & & 3 \\
\hline
\end{tabular}

Keterangan :

- Tuntas $: \frac{24 \times 100}{27}=89$

- Belum Tuntas : $11 \times 100=11$

Perbandingan prestasi belajar pada siklus I dan II

\begin{tabular}{|l|l|l|l|l|l|}
\hline \multirow{2}{*}{ No } & Nama siswa & \multicolumn{2}{|l|}{ Nilai hasil tes } & \multirow{2}{*}{ Perbandingan } \\
\cline { 3 - 5 } & & & Siklus I & Siklus II & 30 \\
\hline 1 & Ahmad Yusuf & & 50 & 80 & \\
\hline
\end{tabular}




\begin{tabular}{|c|c|c|c|c|}
\hline 2 & Arman Dwi Ilham & 60 & 70 & 10 \\
\hline 3 & Dana Maulana & 60 & 90 & 30 \\
\hline 4 & Ezi Putrawan & 80 & 90 & 10 \\
\hline 5 & Halimah & 60 & 80 & 20 \\
\hline 6 & Huswatun Hasanah & 60 & 80 & 20 \\
\hline 7 & Hasniati & 80 & 80 & 0 \\
\hline 8 & Hirfandi & 70 & 70 & 0 \\
\hline 9 & Ida Handayani & 60 & 70 & 10 \\
\hline 10 & Jefrian Abdullah & 60 & 70 & 10 \\
\hline 11 & Lilis Cahyani & 60 & 70 & 10 \\
\hline 12 & Muh,Irwan Hadi & 50 & 60 & 10 \\
\hline 13 & Muh Riski Maulidi & 80 & 80 & 0 \\
\hline 14 & Nurul Suhada & 40 & 60 & 20 \\
\hline 15 & Nurhidayah & 80 & 80 & 0 \\
\hline 16 & Rani Rahmawati & 40 & 70 & 30 \\
\hline 17 & Rozali & 90 & 90 & 0 \\
\hline 18 & Riyan Sahasbi & 90 & 90 & 0 \\
\hline 19 & Suriani & 50 & 70 & 20 \\
\hline 20 & Wahyu Ade Sastrawan & 60 & 70 & 10 \\
\hline 21 & Yeni Regina & 70 & 70 & 0 \\
\hline 22 & Wendi Aulia Febrian & 40 & 60 & 20 \\
\hline 23 & Legina Fatmawati & 50 & 70 & 20 \\
\hline 24 & Nur azizah & 70 & 70 & 0 \\
\hline 25 & Evi Susanti & 70 & 70 & 0 \\
\hline 26 & Nurul Aini & 40 & 80 & 40 \\
\hline \multirow[t]{2}{*}{27} & Sandi Hariawan & 60 & 70 & 10 \\
\hline & Jumlah Nilai & 1680 & 2560 & 880 \\
\hline
\end{tabular}




\begin{tabular}{|l|l|l|l|l|l|}
\hline Nilai tertinggi & & 90 & 90 & 0 \\
\hline Nilai Terendah & 40 & 60 & 20 \\
\hline Rata-Rata /\% & 65 & 75 & 10 \\
\hline
\end{tabular}

\section{Daftar Rujukan}

A. Malik Fadjar. 1999. Reorientasi Pendidikan Islam. Jakarta: Fajar Dunia. Andayani, dkk. 2010. Pemantapan Kemampuan Profesioanl. Jakarta: Universitas Terbuka, Aswani, Zainul. 2005. Komputer dan media Pembelajaran. Jakarta: Universitas Terbuka BNSP. 2006. Standar isi Kompetensi dasar mata Pelajaran Pendidikan kewarganegaraan SD Kelas V. Jakarta: Erlangga.

Gatot, Muhsetyo dkk. 2007. Pembelajaran PKn. Jakarta: Universitas Terbuka.

Mulyani, Sumantri, dan Nana Syodih. 2007. Perkembangan Peserta Didik. Jakarta: Universitas Terbuka.

Samsudin, Abin. 2004. Profesi Keguruan 2. Jakarta: Universitas Terbuka.

Suciati, dkk. 2004. Belajar dan Pembelajaran 2. Jakata: Universitas Terbuka.

Wardani, I.G.A.K. 2008. Penelitian Tindakan Kelas. Jakarta: Universitas Terbuka

Wahyudi Duin, dan Supaiyati, Ishak. 2001. Pengantar Pendidikan. Jakarta: Universitas Terbuka.

Winartaputra, Udin s.dkk. 2006. Materi dan Pembelajaran PKn SD Jakarta: Universitas Terbuka.

Winataputra, dkk. 2004. Strategi belajar Mengajar. Jakarta: Universitas Terbuka.

Setiati, Rahayuningsih Fajar. 2008. PKn SD/MI kelas V. Jakarta: Pusat Perbukuan. 